The Tragic Tale of Claire Ferchaud and the Great War 
This page intentionally left blank 


\section{The Tragic Tale of Claire Ferchaud and the Great War}

Raymond Jonas

UNIVERSITY OF CALIFORNIA PRESS

Berkeley Los Angeles London 
University of California Press

Berkeley and Los Angeles, California

University of California Press, Ltd.

London, England

(C) 2005 by the Regents of the University of California

Unless otherwise noted, photos and illustrations are from the author's collection.

Library of Congress Cataloging-in-Publication Data

Jonas, Raymond Anthony.

The tragic tale of Claire Ferchaud and the Great War / Raymond Jonas.

p. $\mathrm{cm}$.

Includes bibliographical references and index. ISBN 0-520-24297-I (hardcover : alk. paper) ISBN 0-520-24299-8 (pbk. : alk. paper)

I. Ferchaud, Claire, I896-1972. 2. World War, I914-I918Religious aspects-Catholic Church. 3. Sacred Heart, Devotion to-France-History of doctrines-2oth century. I. Title.

$\mathrm{BX}_{4705 . \mathrm{F}_{37} \mathrm{~J} 66 \quad 2005}$

D282'.092- dc22 20040066I 4

Manufactured in the United States of America
$\begin{array}{lllllllll}\text { I3 } & \text { I2 } & \text { II } & \text { IO } & 09 & 08 & 07 & 06 & 05\end{array}$
Iо $\quad 9 \begin{array}{lllllllll} & 8 & 7 & 6 & 5 & 4 & 3 & 2 & \text { I }\end{array}$

The paper used in this publication meets the minimum requirements of ANSI/NISO $Z_{39 \cdot 48-1992}$ (R I997)

(Permanence of Paper). 
For Anthony, Elizabeth, and Katherine 
This page intentionally left blank 
I felt my throat gripped by the terrible hand of hysteria; my sight was dazzled by rebellious tears that refused to fall.

Charles Baudelaire, "Le vieux saltimbanque," I867

The ideal of unmediated reporting is regularly achieved only in fiction, where the writer faithfully reports on what is going on in his imagination.

Janet Malcolm, The Silent Woman, 1995 
This page intentionally left blank 